\title{
PERSEPSI MAHASISWA BISNIS DALAM MEMILIH BEKERJA SEBAGAI WIRAUSAHA, DI UKM ATAU PERUSAHAAN MULTINASIONAL: INVESTIGASI EFEK MODERASI JURUSAN, GENDER, KEPRIBADIAN DAN PROGRAM PENDIDIKAN
}

\author{
Yuniarti Hidayah Suyoso Putra \\ Jurusan Akuntans-Fakultas Ekonomi UIN Maulana Malik Ibrahim Malang \\ E-mail: yuniarti_hidayah@yahoo.com
}

\begin{abstract}
Tight work rivalry demand every student to prepare himself as well as possible. Especially business student who get enterpreneur subject. The interesting thing in this research is to compare perception of business student about work choices as businessman, work in Small and Medium Industy (UKM) or in Multinational Company (MNC) according to their major, gender, personality and education program. The result of this research show that interest to work in company in scale of UKM and Multinational or MNC is bigger than interest to be businessman. Moderating variable that consist of major, gender, personality and education program had an effect on loading factors validity level over standard 0,5 to the perception of student in choose their work as businessman, in UKM. or MNC.

Persaingan kerja yang sangat ketat menuntut setiap mahasiswa untuk mempersiapkan diri dengan sebaik-baiknya. Terutama mahasiswa bisnis yang telah mendapatkan materi kewirausahaan. Hal yang menarik dalam penelitian ini adalah membandingkan persepsi mahasiswa bisnis mengenai pilihan bekerja sebagai wirausaha, bekerja di Usaha Kecil dan Menengah (UKM) atau di perusahaan multinasional (MNC) berdasarkan jurusan, jenis kelamin (gender), kepribadian dan program pendidikan. Hasil penelitian menunjukkan bahwa minat untuk bekerja di perusahaan baik itu skala UKM dan multinational atau MNC lebih besar bila dibandingkan dengan keinginan untuk berwirausaha. Variable moderating yang terdiri dari jurusan, gender, kepribadian,dan program pendidikan berpengaruh dengan tingkat validitas loading factors diatas standar 0,5 terhadap persepsi mahasiswa dalam memilih pekerjaan sebagai wirausaha, di UKM atau MNC.
\end{abstract}

Keywords: Persepsi, Pilihan Bekerja, Efek Moderasi

\section{Pendahuluan}

Lulusan perguruan tinggi dihadapkan berbagai pilihan dalam bekerja. Ada yang berkeinginan bekerja di perusahaan berskala kecil, menengah, besar dan sebagai wirausaha. Pilihan sebagai wirausaha cukup menarik ditinjau dari data jumlah wirausahawan di Indonesia melonjak tajam dari $0,24 \%$ menjadi $1,56 \%$ dari jumlah penduduk. Kementerian Koperasi dan Usaha Kecil dan Menengah optimistis bahwa di tahun 2014 pertumbuhan wirausaha ke titik ideal minimal $2 \%$ dapat tercapai. Data tersebut diperkuat dengan jumlah wirausaha yang awalnya dari $0,18 \%$ wirausaha dari penduduk Indonesia meningkat tiga tahun lalu menjadi angka 0,24\%, dan terakhir Januari 2012 jumlahnya sudah menjadi 1,56\% penduduk Indonesia. Pertumbuhan 1,56\% itu hasil hitungan Deputy Bidang Pengkajian Kemenkop \& UKM berdasarkan data dan kriteria yang ditetapkan oleh BPS sebagai lembaga pemerintah yang di percaya dan kompeten (Fajri, 2012). 
Survei Litbang Kompas awal Oktober 2012, di Jakarta, Bandung, Yogyakarta, Surabaya, dan Makassar merangkum pendapat 301 mahasiswa dari sejumlah perguruan tinggi mengenai kewirausahaan. Hampir semua mahasiswa yang menjadi responden yaitu $91 \%$ menyatakan ketertarikannya untuk membuat usaha sendiri alias berwirausaha. Bahkan, hampir separuh di antaranya mengaku sangat tertarik. Hasil survey dari latar belakang pendidikan, peminatnya lebih banyak berasal dari mahasiswa yang mengambil kuliah ilmu sosial (60\%) dibandingkan dengan mahasiswa dari ilmu eksakta. Selain itu, mahasiswa yang tertarik berwirausaha sebagian besar memiliki pengalaman bekerja sama dalam tim, baik saat mengikuti organisasi intrakampus maupun mencicipi dunia kerja (Sugihandari, 2012).

Seperti di ketahui bahwa Indonesia tertinggal jauh dari negara Asia lainnya seperti China dan Jepang dengan jumlah wirausahawan $10 \%$ dari total populasi, Malaysia 5\%, dan Singapura 7\%. Terlebih lagi di Amerika, lebih dari $12 \%$ penduduknya menjadi entrepreneur. Jumlah pegawai negeri di Indonesia hanya 4 juta orang sehingga pencapaian pertumbuhan yang ada sekarang faktanya memang merupakan kontribusi dari masyarakat dan kalangan swasta. menurut Ciputra, pendiri Universitas Ciputra Entrepreneurship Center (UCEC) untuk membangun ekonomi bangsa dibutuhkan minimal 2\% wirausahawan dari keseluruhan populasi. Kalangan pemuda di Indonesia terbiasa hidup di zona nyaman karena berkah yang dimiliki dengan sumber daya alam (SDA) yang berlimpah. Sementara SDA itu harus diolah agar memiliki manfaat dan nilai tambah yang tinggi. Sedangkan di negara tetangga dan belahan negeri lain karena sumber daya alam yang terbatas maka kalangan pemudanya ditantang berkreasi untuk mengatasi keterbatasannya (Fajri, 2012).

Selain berwirausaha, pilihan karir yang kedua adalah bekerja di Usaha Kecil dan Menengah (UKM). Keberadaan UKM sebagai penyedia lapangan kerja telah memberi kontribusi yang sangat besar. Tenaga kerja yang dapat ditampung oleh UKM semakin meningkat. Hal ini membuktikan bahwa UKM mampu mengatasi masalah pengangguran yang menjadi masalah bangsa ini. Pada tahun 2012, UKM mampu menyerap tenaga kerja sebesar 107.657 .509 orang atau 97,24\% dari total penyerapan tenaga kerja yang ada. Jumlah ini meningkat sebesar 5,83\% atau 5.935.051 orang dibanding tahun 2011. Kontribusi dalam hal penyerapan tenaga kerja oleh UKM ini lebih besar dibanding dengan penyerapan tenaga kerja pada Usaha Besar (UB). Pada tahun 2011 UB hanya mampu menyerap tenaga kerja sebesar 2.891.224 dan pada tahun 2012 sebesar 3.150.645 orang atau pada tahun 2011 dan tahun 2012, usaha besar hanya mampu menampung $2,76 \%$ dan $2,84 \%$ dari total penyerapan tenaga kerja yang ada (BPS, 2012).

Meskipun data yang diperoleh menunjukkan minat yang besar untuk bekerja sebagai wirausaha maupun bekerja di UKM. Hasil riset di Amerika Serikat menunjukkan mayoritas mahasiswa lebih memilih untuk bekerja diperusahaan besar setelah wisuda meskipun jumlah usaha kecil yang beroperasi lebih besar dari perusahaan besar (Hollingwosworth, Klatt dan Zimmerer, 1974; Teo dan Poon, 1994; Moy dan Lee, 2002). Salah satu penyebabnya adalah kemampuan untuk menarik tenaga kerja menjadi hal yang sangat penting bagi kesuksesan usaha apapun ukuran perusahaan.

Berdasarkan latar belakang tersebut maka Penelitian ini bertujuan untuk 1) membandingkan persepsi mahasiswa bisnis mengenai pilihan bekerja sebagai wirausaha, bekerja di Usaha Kecil dan Menengah (UKM) atau di perusahaan multinasional (MNC) berdasarkan jurusan, jenis kelamin (gender), kepribadian dan program pendidikan; 2) membantu menentukan apa persepsi mahasiswa terhadap preferensi kerja berdasarkan 10 faktor pekerjaan, dan 3) menginvestigasi gender, kepribadian dan program pendidikan sebagai moderator untuk menyelidiki potensi karakteristik lain yang mempengaruhi persepsi mahasiswa bekerja sebagai wirausaha, di UKM atau di MNC.

Beberapa penelitian tentang persepsi mahasiswa tentang pilihan bekerja telah dilakukan, diantaranya di Amerika Serikat (Lee Grubb, Harris dan MacKenzie, 2007; 
Hollingwosworth, Klatt dan Zimmerer, 1974), Hong Kong (Moy dan Lee, 2002), Singapura (Teo dan Poon, 1994), Belanda (Van der Sijde, Nair dan During, 2013). Penelitian tersebut befokus pada persepsi mahasiswa terhadap pilihan bekerja di UKM atau di MNC. Sedangkan penelitian terhadap persepsi mahasiswa bisnis atas pilihan berkarir sebagai wirausaha, di UKM atau di MNC belum pernah dilakukan di Indonesia. Survey yang dilakukan oleh Litbang Kompas (Sugihandari, 2012) lebih pada pemetaan potensi bidang wirausaha yang diminati oleh mahasiswa.

Terdapat beberapa pertimbangan mengapa persepsi mahasiswa bisnis penting dalam pilihan bekerja sebagai wirausaha, bekerja di UKM atau di perusahaan multinasional (MNC) antara lain, pertama, mahasiswa bisnis dibentuk untuk menjadi professional di bidang bisnis dengan dibekali keahlian dan ketrampilan penunjang kompetensinya. Kedua, beberapa universitas besar di Indonesia mencanangkan diri sebagai World Class University (WCU) dan ada pula yang mencanangkan sebagai Entrepreneurship University. Salah satu syarat universitas yang sudah go WCU adalah mahasiswanya kompeten dalam berbahasa Internasional yaitu bahasa Inggris. Kompetensi dalam penguasaan bahasa Inggris ini banyak dibutuhkan di perusahaan-perusahaan multinasional (MNC) dibandingkan di UKM atau berwirausaha kecuali jika bergerak dibidang ekspor impor. Sehingga perlu dilakukan penelitian yang lebih mendalam terhadap minat mahasiswa bisnis dalam berkarir.

Hasil penelitian terhadap persepsi mahasiswa ini memiliki manfaat yang sangat signifikan 1) untuk review muatan mata kuliah kewirausahaan agar bisa mengakomodir situasi bisnis terkini, 2) sebagai dasar pengembangan kurikulum masing-masing jurusan atau program pendidikan, 3) pengembangan kompetensi serta keterampilan yang dapat menunjang mahasiswa dalam pemilihan karirnya dan 4) dasar perencanaan lulusan unggulan untuk bekerja di lini bisnis utama terutama yang menunjang laju perkembangan UIN Maulana Malik Ibrahim sebagai salah satu WCU.

\section{Faktor Pekerjaan (Job Factors) sebagai Wirausaha, di UKM dan MNC}

Studi yang dilakukan oleh Teo dan Poon (1994) meneliti persepsi mahasiswa Singapura terhadap UKM dan perusahaan multinasional. 270 mahasiswa yang terdaftar dalam program akuntansi dan program bisnis disurvei untuk menentukan persepsi mereka terhadap UKM dan MNC berdasarkan 10 faktor pekerjaan. Hasil penelitian mengindikasikan bahwa MNC dianggap lebih menguntungkan daripada UKM dalam hal 6 dari 10 factor pekerjaan yang diuji yaitu faktor: gaji (pay), tunjangan (fringe benefits), kondisi kerja (working conditions), prospek karir jangka panjang (long-term career prospects), kelayakan untuk diperkerjakan (marketability) dan keamanan kerja (job security). Sedangkan UKM dianggap lebih menguntungkan daripada perusahaan multinasional (MNC) pada 4 faktor pekerjaan yang tersisa dari 10 faktor yang diuji yaitu dalam hal kualitas manajerial dan hubungan kerja (managerial quality and relationships), tanggung jawab yang diberikan (responsibility given), kewenangan yang diberikan (authority given) dan keterlibatan dalam pengambilan keputusan (involvement in decision making).

Secara keseluruhan, pekerjaan di MNC disukai oleh yang bekerja di UKM. Temuan Teo dan Poon menunjukkan persepsi yang sedikit berbeda antara mahasiswa S1 Bisnis dan S1 Akuntansi. Kedua kelompok melihat perbedaan antara UKM dan perusahaan multinasional dalam hal sama, namun ketika nilai-nilai diterapkan untuk 10 faktor pekerjaan di UKM secara individual, Jurusan S1 Bisnis melihat UKM kurang menguntungkan bila dibandingkan dengan Jurusan Akuntansi. Riset Teo dan Poon (1994) juga menunjukkan bahwa tidak ada perbedaan persepsi antar mahasiswa laki-laki dan perempuan terhadap UKM dan MNC tentang 10 faktor pekerjaan yang menentukan mahasiswa memilih karir. Baik mahasiswa laki-laki dan perempuan lebih memilih pekerjaan di MNC dibandingkan di UKM dalam hal 6 faktor pekerjaan berikut: gaji (pay), tunjangan (fringe benefits), kondisi kerja 
(working conditions), prospek karir jangka panjang (long-term career prospects), kelayakan untuk diperkerjakan (marketability) dan keamanan kerja (job security). Sedangkan UKM dipandang sebagai lebih menguntungkan dalam hal kualitas manajerial dan hubungan kerja (managerial quality and relationships), tanggung jawab yang diberikan (responsibility given), kewenangan yang diberikan (authority given) dan keterlibatan dalam pengambilan keputusan (involvement in decision making).

Riset yang dilakukan oleh Moy dan Lee (2002) juga meneliti persepsi mahasiswa terhadap UKM dan MNC. Survei dilakukan kepada 200 siswa yang terdaftar dalam kelas Manajemen Strategi di sebuah Universitas di Hong Kong. Mahasiswa diminta untuk peringkat faktor pekerjaan yang yang ditawarkan oleh UKM dan MNC untuk menentukan keputusan relatif mereka dalam karir. Mahasiswa kemudian diminta untuk men-skor UKM dan perusahaan multinasional atas dasar masing-masing faktor pekerjaan. Hasil penelitian menunjukkan bahwa lulusan jurusan bisnis lebih kuat menekankan pada pentingnya imbalan ekstrinsik saat menilai paket pekerjaan yang ditawarkan oleh perusahaan multinasional dibandingkan dengan paket yang ditawarkan oleh UKM. Mahasiswa merasa UKM kurang menguntungkan dibandingkan MNC dalam 5 faktor pekerjaan yaitu gaji (pay), tunjangan (fringe benefits), kondisi kerja (working conditions), prospek karir jangka panjang (long-term career prospects), kelayakan untuk dipekerjakan (marketability). UKM dipandang lebih menguntungkan daripada MNC dalam hal kualitas manajerial dan hubungan kerja (managerial quality and relationships), tanggung jawab yang diberikan (responsibility given). Baik UKM dan MNC dilihat sama dalam hal keamanan kerja (job security) dan keterlibatan dalam pengambilan keputusan (involvement in decision making). Hasil penelitian Moy dan Lee (2002) ini mirip dengan temuan dari Teo dan Poon (1994).

Hasil penelitian sebelumnya tersebut menunjukkan mahasiswa mempersepsikan bahwa MNC menawarkan manfaat lebih besar dari UKM, sehingga lebih menguntungkan bagi mereka untuk memulai karier di MNC besar (Teo \& Poon, 1994; Moy \& Lee, 2002). Namun, tidak satupun dari studi ini menginvestigasi variable moderating individual yang dapat membantu memahami atau menjelaskan persepsi mahasiswa tersebut. Sehingga Lee Grubb, Harris dan MacKenzie (2007) mereplikasi penelitian Teo dan Poon (1994) dalam rangka membantu meningkatkan pemahaman kita tentang persepsi mahasiswa Amerika terhadap UKM dan MNC dengan menambahkan variable jurusan, jenis kelamin (gender), dan dimensi kepribadian. Hasil penelitian diharapkan dapat membantu organisasi, baik besar maupun kecil, dalam memasarkan organisasi mereka untuk calon lulusan yang potensial.

Lee Grubb, Harris dan MacKenzie (2007) mengumpulkan data selama musim gugur dan musim semi semester tahun ajaran 2004-2005 dari salah satu universitas besar di Amerika Serikat bagian Tenggara. Sampel dari 395 mahasiswa S1 Bisnis digunakan, termasuk $78(21,0 \%)$ mahasiswa jurusan akuntansi, 91 (24,5\%), mahasiswa jurusan pemasaran, $111(30,0 \%)$ mahasiswa jurusan manajemen dan $91(24,5 \%)$ mahasiswa jurusan keuangan. Usia rata-rata mahasiswa adalah 22.04, dan 56,7\% adalah laki-laki. Mahasiswa Kaukasia menyumbang 83,5\% dari sampel, diikuti oleh Afrika-Amerika (10,1\%), Asia dan Kepulauan Pasifik (1,8\%), Hispanik (1,5\%), Lain-lain (1,3\%), dan American Indian (0,5\%). Hasil penelitian ini menunjukkan bahwa mahasiswa akuntansi, pemasaran, dan keuangan mahasiswa menyukai pekerjaan masa depannya di MNC, sedangkan mahasiswa manajemen menyukai karir di UKM. Temuan ini berbeda dari temuan Teo dan Poon (1994). Teo dan Poon menemukan bahwa semua mahasiswa bisnis siswa lebih memilih kerja di masa depan dengan perusahaan multinasional. Menariknya, Teo dan Poon mengamati bahwa mahasiswa akuntansi tampaknya menganggap pekerjaan dengan UKM lebih menguntungkan daripada jurusan bisnis yang lain, sementara temuan Lee Grubb, Harris dan MacKenzie (2007) menunjukkan bahwa mahasiswa Manajemen memiliki keinginan yang lebih kuat untuk kerja di masa depan dengan UKM. 
Minat yang besar tersebut patut diapresiasi, namun sebagai wirausahawan (entrepreneur) adalah menjadi seseorang yang berani mengambil risiko, mampu mencium adanya peluang bisnis, mampu mendayagunakan sumber daya secara efektif dan efisien untuk memperoleh profit. Meskipun hampir semua responden mahasiswa setuju dengan pernyataan bahwa berwirausaha penuh risiko, mereka memandangnya sebagai sebuah tantangan. Bahkan, mayoritas (77\%) menilai, profesi ini membanggakan. Apalagi, jika ingin terjun ke usaha mandiri ini, tidak selalu membutuhkan modal yang besar. Setidaknya sekitar separuh responden berpendapat demikian. Persepsi-persepsi positif tersebut membangun bayangan usaha yang ingin dibuat responden. Tidak kurang dari $67 \%$ responden mahasiswa yang berminat menjadi wirausaha memilih usaha-usaha yang mengambil peran sebagai produsen, sementara sisanya distributor barang. Hal ini memungkinkan berkembangnya aspek kreatif dan inovatif yang diharapkan dari semangat kewirausahaan. Dana dan pendampingan dari yang lebih berpengalaman di bidang ini sudah banyak tersedia sehingga seharusnya bukan menjadi kendala utama. Namun persiapan mental pelakunya menjadi tantangan utama. Menjadi wirausaha tidak berhenti pada fase ketika bisnis sudah berkembang dan laris, inovasi harus terus-menerus dilakukan karena itulah intinya kewirausahaan. Dalam proses inilah kembali dibutuhkan totalitas yang konsisten (Sugihandari, 2012).

Berdasarkan temuan pada penelitian-penelitian terdahulu maka hipotesis yang dikembangkan adalah:

H1 : Mahasiswa semua jurusan akan lebih suka bekerja untuk perusahaan multinasional (MNC) daripada di UKM atau berwirausaha.

\section{Perspektif Gender}

Riset Teo dan Poon (1994) menemukan bahwa kebanyakan mahasiswa akuntansi dan bisnis tidak melihat bekerja dengan UKM sebagai pilihan yang menarik setelah lulus. Hasil penelitian mereka juga menunjukkan bahwa mahasiswa laki-laki dan perempuan memiliki persepsi yang sama tentang berbagai faktor pekerjaan Lulusan baru fakultas bisnis sering mencari penghargaan ekstrinsik dalam pekerjaan awal mereka dan melihat MNC sebagai alternatif yang lebih menarik dari segi gaji (pay) dan tunjangan atau fringe benefits (Moy dan Lee, 2002).

Sedangkan hasil penelitian Lee Grubb, Harris dan MacKenzie (2007) menunjukkan hasil yang berbeda mahasiswa laki-laki dan perempuan memiliki preferensi kerja berbeda yaitu mahasiswa perempuan lebih banyak mendukung MNC, sedangkan mahasiswa laki-laki lebih memilih UKM. Untuk membuktikan apakah terdapat perbedaan persepsi antara mahasiswa laki-laki dengan mahasiswa perempuan dalam pemilihan karir wirausaha, di UKM atau di MNC maka hipotesis berikut diformulasikan.

H2 : Mahasiswa laki-laki dan perempuan akan lebih suka bekerja untuk perusahaan multinasional (MNC) daripada di UKM atau berwirausaha.

\section{Dimensi Kepribadian}

Dimensi kepribadian diteliti untuk menyelidiki hubungan potensali karakteristik lain yang mempengaruhi persepsi mahasiswa bekerja sebagai wirausaha, di UKM atau di MNC. Berdasarkan penelitian yang dilakukan oleh Lee Grubb, Harris dan MacKenzie (2007), 5 dimensi besar kepribadian yang ditemukan oleh Goldberg (1981) digunakan. Kelima sifat kepribadian itu adalah ekstroversi (extroversion), keramahan (agreeableness), kesadaran (conscientiousness), kestabilan emosi (emotional stability) dan keterbukaan terhadap pengalaman (openness to experience).

Keterbukaan terhadap pengalaman (openness to experience) mengacu pada sejauh bahwa seorang individu secara intelektual ingin tahu dan kreatif dan fleksibel (Watson \& Clark, 1997). Keramahan (agreeableness) mengacu pada tingkat bahwa individu 
menyenangkan, ramah, kooperatif dan mencari hubungan pribadi memuaskan (McCrae dan Costa, 1991). Kesadaran (conscientiousness) dapat digambarkan sebagai sejauh bahwa individu dapat diandalkan, handal, dan terorganisir. Kesadaran juga berarti bahwa individu tersebut tertib, setia, dan persisten. Kesadaran juga diyakini terkait dengan etos kerja keras yang mengarah ke penghargaan yang lebih besar seperti gaji yang lebih tinggi dan promosi (Organ \& Lingl, 1995). Kestabilan emosi (emotional stability) mengarah pada tingkat kecemasan individu dan tingkat ketidakaman. Ketidakstabilan emosi individu dapat menunjukkan kurangnya kemampuan untuk menyesuaikan diri dan menangani secara efektif kejadian-kejadian dalam kehidupan yang bersifat negatif (Suls, Hijau, dan Hillis, 1998). Sedangkan ekstroversi (extroversion) mengacu pada tingkat asertif individu misalnya mudah bergaul dan gemar berbicara.

Keramahan (agreeableness) adalah dimensi kepribadian telah lama dikaitkan dengan ramah, hubungan kooperatif yang dilakukan individu. Menurut Teo dan Poon (1994), mahasiswa Singapura percaya bahwa UKM menawarkan hubungan manajerial yang lebih tinggi. Berdasarkan informasi tersebut maka hipotesis berikut ini diformulasikan:

H3 : Keramahan (agreeableness) akan berhubungan positif dengan preferensi bekerja di UKM daripada di perusahaan multinasional (MNC) atau berwirausaha.

Selain itu, tingginya tingkat keterbukaan terhadap pengalaman (openness to experience) telah dikaitkan dengan individu yang kreatif dan secara intelektual ingin tahu. Teo dan Poon (1994) lapangan kerja di UKM menawarkan tanggung jawab lebih besar, wewenang dan keterlibatan dalam pengambilan keputusan. Berdasarkan keyakinan bahwa individu yang kreatif dan memiliki rasa ingin tahu yang intelek akan lebih suka bekerja untuk sebuah organisasi yang memungkinkan mereka untuk menjadi kreatif dan lebih terlibat dengan pengambilan keputusan. Sehingga diduga bahwa keterbukaan yang tinggi membuat individu akan lebih memilih UKM.

H4 : Keterbukaan (openness to experience) terhadap pengalaman akan berhubungan positif dengan preferensi untuk bekerja dengan UKM daripada di perusahaan multinasional (MNC) atau berwirausaha.

Individu yang memiliki kesadaran (conscientiousness) tinggi dianggap lebih loyal dan gigih dan memiliki etika kerja yang lebih tinggi, yang dapat membawa kesuksesan yang lebih besar, gaji yang lebih tinggi dan promosi. Teo dan Poon (1994) mencatat bahwa mahasiswa percaya ada kesempatan yang lebih besar untuk gaji dan prospek karir jangka panjang di MNC. Oleh karena itu diduga bahwa individu-individu yang memberikan nilai tinggi pada dimensi kesadaran mungkin memilih untuk bekerja untuk perusahaan multinasional (MNC) yang menawarkan gaji dan kemajuan peluang yang lebih besar.

H5 : Kesadaran (conscientiousness) akan berhubungan positif dengan preferensi untuk bekerja di perusahaan multinasional (MNC) daripada di UKM atau berwirausaha.

Kestabilan emosi (emotional stability) mengacu pada tingkat kecemasan seseorang dan seberapa aman mereka. Individu yang kestabilan emosinya kurang mungkin akan lebih yakin bekerja untuk sebuah MNC di mana terdapat persepsi bahwa MNC menawarkan keamanan kerja dan kondisi kerja yang lebih baik dari UKM.

H6 : Kestabilan emosi (emotional stability) akan berhubungan positif dengan preferensi untuk bekerja dengan perusahaan multinasional (MNC) daripada di UKM atau berwirausaha. 
Sedangkan extroversion berhubungan dengan kemudahan individu dalam bergaul dan sikap assertif atau tegas. Individu dengan skor extroversion yang tinggi diyakini untuk mencari pekerjaan yang berhubungan dengan interaksi dan hubungan yang bermanfaat. Meskipun UKM yang dianggap memiliki hubungan manajerial berkualitas tinggi, daya tarik UKM ke individu yang ekstrovert memiliki perbedaan yang tipis dengan di perusahaan multinasional. Kita percaya bahwa ekstrovert mungkin sama-sama sukses baik di UKM dan perusahaan multinasional ekstroversi mungkin tidak menjadi prediktor preferensi untuk pekerjaan baik UKM atau perusahaan multinasional.

H7 : Tidak ada hubungan yang signifikan antara ekstroversi dan preferensi untuk pekerjaan di UKM atau MNC atau berwirausaha.

Demikian pula dengan program pendidikan S1 dan D3 memiliki kesempatan yang sama untuk berkerja sebagai wirausaha, bekerja di UKM atau bekerja di perusahaan multinasional (MNC). Sehingga diduga:

H8 : Tidak ada hubungan yang signifikan antara program pendidikan dan preferensi untuk pekerjaan di UKM atau MNC atau berwirausaha.

\section{Metode Penelitian}

Penelitian ini adalah penelitian deskriptif kuantitatif yang bertujuan untuk membandingkan persepsi mahasiswa bisnis mengenai pilihan bekerja sebagai wirausaha, bekerja di UKM dan di MNC dan menginvestigasi apakah jurusan, gender, tipe kepribadian, dan program pendidikan yang diambil memiliki pengaruh terhadap persepsi pilihan pekerjaan tersebut.

Subyek penelitian adalah mahasiswa bisnis di universitas negeri yang mencanangkan atau berorientasi pada world class university di kota Malang, dan telah menempuh mata kuliah kewirausahaan. Mahasiswa berasal dari tiga jurusan yaitu akuntansi, manajemen, dan manajemen perbankan. Program pendidikan yang ditempuh terdiri dari tingkat S1 dan D3.

Kuesioner digunakan untuk menentukan job factors (factor-faktor apa yang mempengaruhi pekerjaan). Mahasiswa diminta untuk menilai persepsinya mengapa memilih bekerja sebagai wirausaha, UKM atau MNC berdasarkan 10 indicator pemilihan pekerjaan. Pertanyaan mengenai faktor-faktor pekerjaan menggunakan skala 1 sampai dengan 5 dengan angka 1 (sangat baik) dan 5 (sangat buruk).

Dimensi kepribadian diselidiki menggunakan Goldberg Big Five Personality yang terdiri dari ekstroversi (extroversion), keramahan (agreeableness), kesadaran (conscientiousness), kestabilan emosi (emotional stability) dan keterbukaan terhadap pengalaman (openness to experience). Kuisioner dimensi kepribadian disusun berdasarkan International Personality Item Pool (2001) dengan 50 daftar pertanyaan. Data dikumpulkan selama 3 bulan mulai bulan Mei sampai dengan Juli 2014.

Konstruk atau variable laten tidak dapat diukur secara langsung, sehingga memerlukan indicator sebagai alat ukur. Pendefinisian indicator berdasarkan studi literature dan penelitian terdahulu yang telah dibahas di bab sebelumnya atau dapat melalui focuss group discussion (Yamin dan dan Kurniawan, 2011). Rincian konstruk beserta indikatornya diilustrasikan sebagai berikut: konstruk job factors memiliki indicator Gaji (X1), Tunjangan (X2), Kondisi Kerja (X3), Kualitas Managerial (X4), Prospek Karir Jangka Panjang (X5), Tanggung jawab yang diberikan (X6), Otoritas yang diberikan (X7), Keterlibatan dalam Pengambilan Keputusan (X8), Marketability (X9) dan Keamanan Kerja (X10). Konstruk jurusan (X11) dengan indicator akuntansi, manajemen dan perbankan. Konstruk gender (X12) dengan indicator laki-laki dan perempuan. Konstruk kepribadian dengan indicator 
Agreeableness (X13), high openness (X14), conscientiousness (X15), Kestabilan emosi (X16) dan Extraversion (X17). Sedangkan konstruk program pendidikan (X18) memiliki indicator D3 serta S1, dan konstruk pilihan pekerjaan indikatornya wirausaha (Y1), UKM (Y2), dan MNC (Y3).

Statistik deskriptif digunakan untuk menyoroti tendensi sentral dan variabilitas dalam sampel. Analisis jalur menurut Yamin dan Kurniawan (2011) digunakan untuk menentukan apakah terdapat hubungan yang signifikan antara preferensi kerja, jurusan, gender, dimensi kepribadian dan program pendidikan. Temuan yang digunakan untuk menguji hipotesis, menarik kesimpulan, dan memetakan potensi penelitian untuk masa depan.

\section{Hasil Penelitian Dan Pembahasan Profil Responden}

Mahasiswa bisnis yang menjadi responden untuk jurusan S1 semua berada pada semester 6 dan telah menempuh mata kuliah kewirausahaan. Sedangkan semua responden mahasiswa D3 berada di semester 4 dan telah menerima mata kuliah kewirausahaan. Berikut adalah data responden mahasiswa bisnis, Fakultas Ekonomi UIN Maulana Malik Ibrahim Malang, dan terdiri dari 3 jurusan yaitu S1 Akuntansi, S1 Manajemen, dan D3 Perbankan Syariah.

Kuisioner yang disebarkan untuk memperoleh gambaran tentang persepsi mahasiswa bisnis terkait dengan prospek pilihan bekerja setelah lulus berjumlah 72 untuk mahasiswa jurusan S1 Akuntansi, 120 untuk jurusan S1 Manajemen, dan 57 untuk jurusan D3 Perbankan Syariah. Jumlah yang kembali dan dikurangi dengan kelengkapan data maka diperoleh data responden yang digunakan untuk memberikan gambaran tentang preferensi pekerjaan sebanyak 222 responden, dan terdiri dari 71 mahasiswa jurusan S1 akuntansi, 105 mahasiswa jurusan S1 MAnajemen serta 45 mahasiswa jurusan D3 perbankan syariah. Jika dilihat dari sebaran gender jumlah laki-laki 92, sedangkan perempuan 129. Mahasiswa yang memilih bekerja berwirausaha sebanyak 39, bekerja di UKM 136, UKM 15 dan 70 bekerja di MNC sebagai pilihan utama

\section{Faktor Pekerjaan (Job Factors) sebagai Wirausaha, di UKM dan MNC}

Gambar 1 menunjukkan bahwa minat untuk bekerja di perusahaan baik itu skala UKM dan multinational atau MNC lebih besar bila dibandingkan dengan keinginan untuk berwirausaha. Pada gambar tersebut belum dimasukkan variable moderasi yaitu jurusan, gender, kepribadian dan program pendidikan. Hasil analisis jalur di gambar 1 menunjukkan bahwa $\mathbf{H 1}$ diterima yang menduga bahwa: Mahasiswa semua jurusan akan lebih suka bekerja untuk perusahaan multinasional (MNC) daripada di UKM atau berwirausaha.

Hal tersebut dibuktikan dengan loading factor yang lebih dari 0,5 menurut Yamin dan Kurniawan (2011) yang berarti valid dan tidak perlu dikeluarkan dari model, yaitu dengan nilai sebesar 1,744 untuk pilihan bekerja di UKM dan 1, 481 untuk perusahaan multinasional atau MNC.

Faktor pekerjaan (job factors) yang berpengaruh paling besar antara lain yaitu gaji (X1), tunjangan (X2), kondisi kerja (X3), tanggung jawab yang diberikan (X6), otoritas yang diberikan (X7), keterlibatan dalam pengambilan keputusan (X8), marketability (X9) dan keamanan kerja (X10). Hasil penelitian ini berbeda dengan riset yang dilakukan Moy dan Lee (2002) dan penelitian Teo dan Poon (1994). Penelitian Moy dan Lee (2002) mengindikasikan mahasiswa merasa UKM kurang menguntungkan dibandingkan MNC dalam 5 faktor pekerjaan yaitu gaji (pay), tunjangan (fringe benefits), kondisi kerja (working conditions), prospek karir jangka panjang (long-term career prospects), kelayakan untuk dipekerjakan 
(marketability). UKM dipandang lebih menguntungkan daripada MNC dalam hal kualitas manajerial dan hubungan kerja (managerial quality and relationships), tanggung jawab yang diberikan (responsibility given). Baik UKM dan MNC dilihat sama dalam hal keamanan kerja (job security) dan keterlibatan dalam pengambilan keputusan (involvement in decision making). Hasil penelitian Moy dan Lee (2002) ini mirip dengan temuan dari Teo dan Poon (1994).

Hasil analisis adalah:

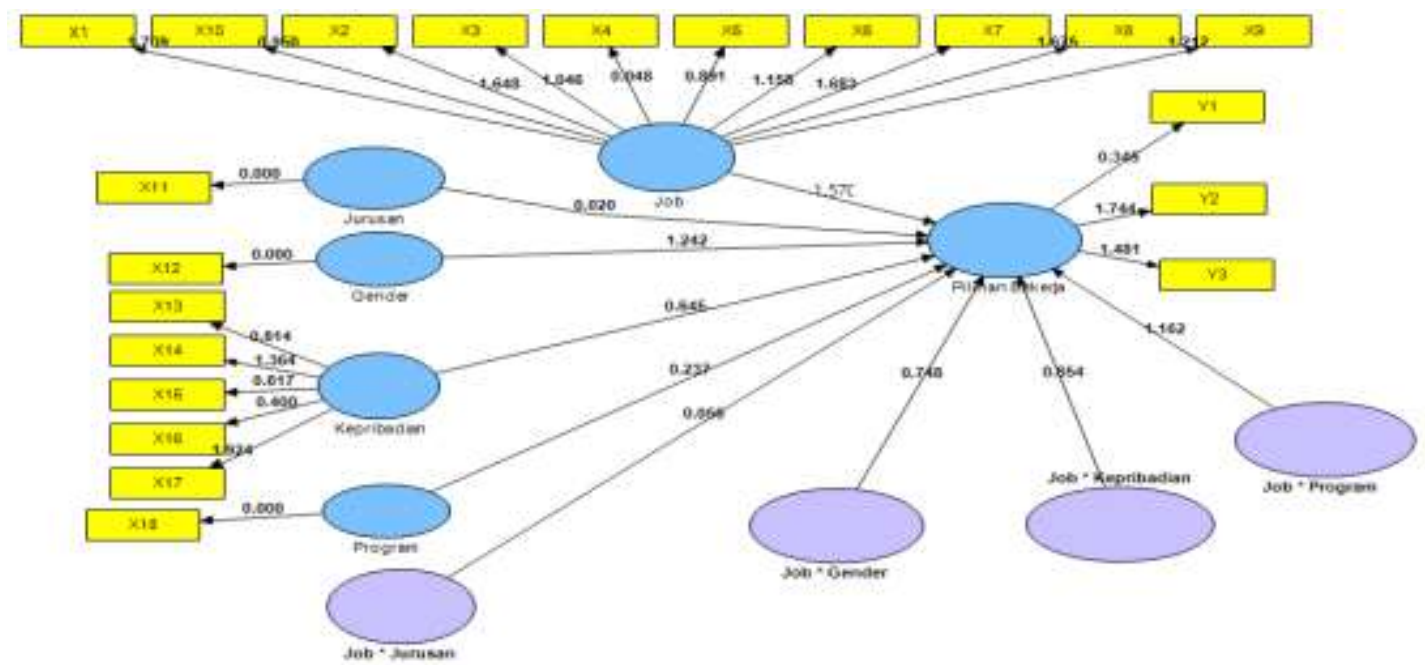

\section{Gambar 1. Persepsi Mahasiswa terhadap Pilihan Bekerja sebagai Wirausaha, UKM atau MNC sebelum di Moderasi}

Jalur pada gambar 1 menunjukkan bahwa mahasiswa Fakultas Ekonomi UIN Maulana Malik Ibrahim lebih meminati untuk bekerja di UKM dibandingkan dengan MNC. Salah satu factor penyebabnya bisa dikarenakan pemahaman akan UKM menjadi salah satu minat pengembangan akademik yang dilakukan di Fakultas Ekonomi tersebut. Minat yang besar terhadap dunia wirausaha memang patut diapresiasi, namun sebagai wirausahawan (entrepreneur) adalah menjadi seseorang yang berani mengambil risiko, mampu mencium adanya peluang bisnis, mampu mendayagunakan sumber daya secara efektif dan efisien untuk memperoleh profit. Menjadi wirausaha tidak berhenti pada fase ketika bisnis sudah berkembang dan laris, inovasi harus terus-menerus dilakukan karena itulah intinya kewirausahaan. Dalam proses inilah kembali dibutuhkan totalitas yang konsisten (Sugihandari, 2012).

Gambar 2. Persepsi Mahasiswa Bisnis FE UIN Maliki Malang terhadap Pemilihan Bekerja sebagai Wirausaha, UKM atau MNC dengan Jurusan sebagai Variabel Moderating 


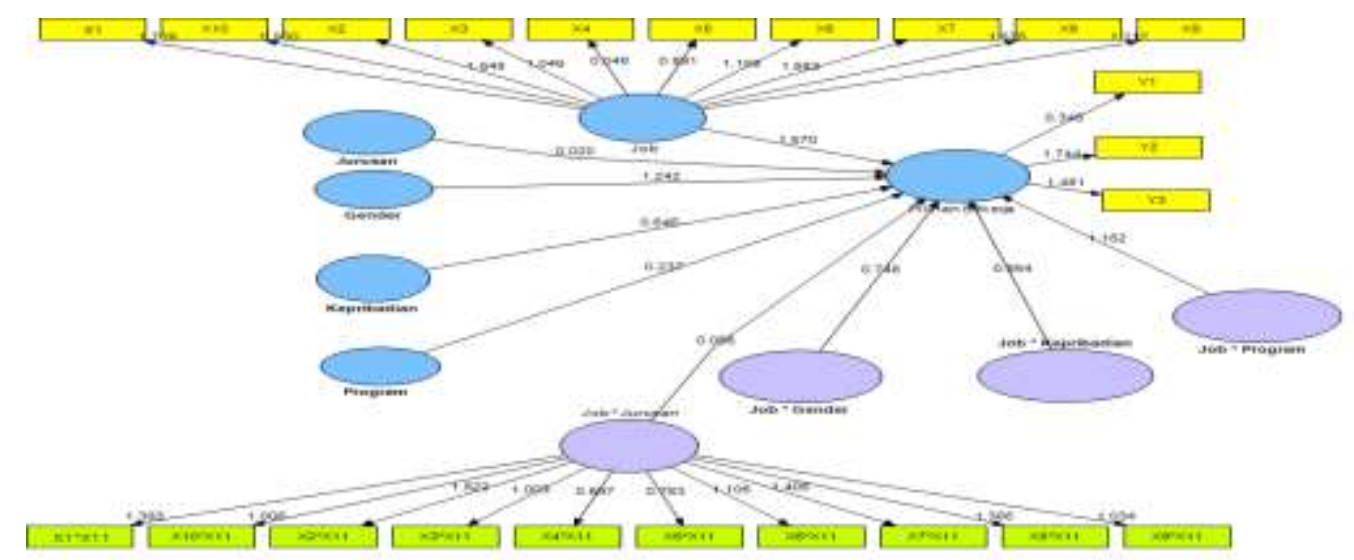

Gambar 2 menunjukkan hasil detail analisis jalur pengaruh jurusan terhadap persepsi mahasiswa bisnis dalam memilih preferensi pekerjaan di masa yang akan datang. Sebagai variable moderasi, jurusan (X11) memiliki pengaruh terhadap pemilihan pekerjaan. Pada saat dikalkulasi, pengaruh langsung jurusan terhadap pemilihan pekerjaan loading factornya tidak valid yaitu 0,056 dibawah batasan validitas 0,5 (Yamin dan Kurniawan, 2011). Akan tetapi jika jurusan dijadikan variable moderating antara job factors dengan preferensi pemilihan pekerjaan loading factornya significant, yaitu memoderasi gaji (X1) sebesar 1,392; tunjangan (X2) sebesar 1,522; tanggung jawab yang diberikan (X6)yaitu 1,105; otoritas yang diberikan (X7) yaitu 1,105 dan keterlibatan (X8) sebesar 1,386.

Hasil penelitian ini berbeda dari riset sebelumnya, misalnya riset Teo dan Poon (1994) menemukan bahwa kebanyakan mahasiswa akuntansi dan bisnis tidak melihat bekerja dengan UKM sebagai pilihan yang menarik setelah lulus. Teo dan Poon (1994) juga menunjukkan bahwa mahasiswa laki-laki dan perempuan memiliki persepsi yang sama tentang berbagai faktor pekerjaan Lulusan baru fakultas bisnis sering mencari penghargaan ekstrinsik dalam pekerjaan awal mereka dan melihat MNC sebagai alternatif yang lebih menarik dari segi gaji (pay) dan tunjangan atau fringe benefits (Moy dan Lee, 2002). Sedangkan hasil penelitian Lee Grubb, Harris dan MacKenzie (2007) menunjukkan hasil yang berbeda mahasiswa laki-laki dan perempuan memiliki preferensi kerja berbeda yaitu mahasiswa perempuan lebih banyak mendukung MNC, sedangkan mahasiswa laki-laki lebih memilih UKM.

\section{Perspektif Gender}

Gender juga memiliki pengaruh yang kuat terhadap pemilihan kerja sebagai wirausaha, di UKM maupun di MNC dengan loading factor sebesar 1,242. Namun tidak ditemukan apakah mahasiswa laki-laki berbeda dengan mahasiswa perempuan dalam hal memilih preferensi kerja di masa yang akan datang. Hasil penelitian menunjukkan bahwa dugaan dalam $\mathbf{H 2}$ ini diterima, yaitu: mahasiswa laki-laki dan perempuan akan lebih suka bekerja untuk perusahaan multinasional (MNC) daripada di UKM atau berwirausaha

Baik mahasiswa laki-laki maupun mahasiswa perempuan lebih suka bekerja untuk perusahaan multinasional dan di UKM dibandingkan bekerja sebagai wirausaha. Adanya kesetaraan hak bagi laki-laki dan perempuan dalam memperoleh pendidikan dan bekerja di perusahaan menjadi salah satu factor penyebabnya.

Ketika berfungsi sebagai variable moderasi, loading factor dari varibel gender masih valid yaitu diatas 0,5 . Pengauh tersebesar adalah memoderasi job factor terkait kondisi kerja (X3), marketability (X9) dan Keamanan kerja (X10). Hasil analisis jalur dengan gender sebagai varibel moderasi diilustrasikan pada gambar 3. 


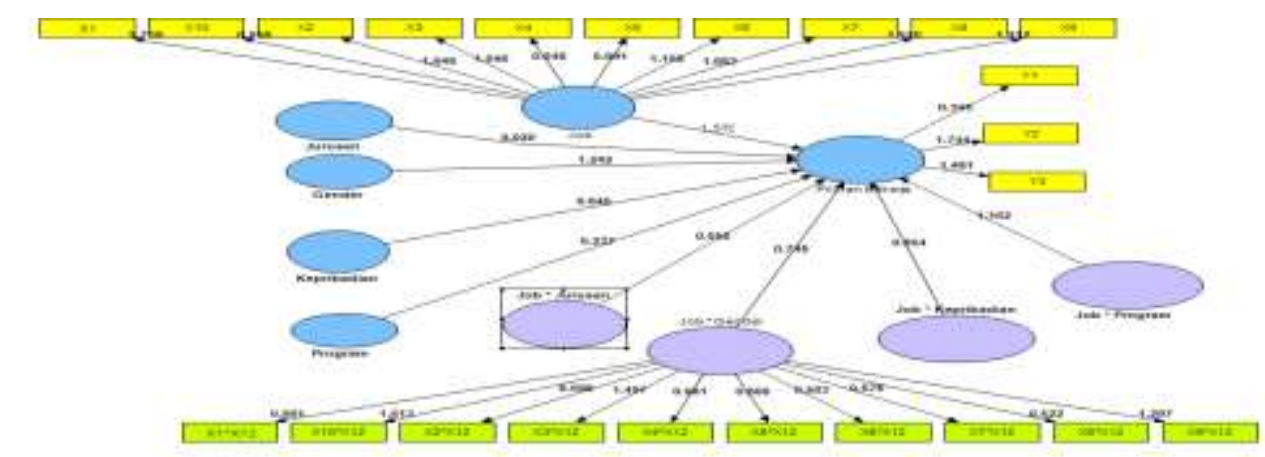

\section{Gambar 3. Persepsi Mahasiswa Bisnis FE UIN Maliki Malang terhadap Pemilihan Bekerja sebagai Wirausaha, UKM atau MNC dengan Gender sebagai Variabel Moderating}

\section{Dimensi Kepribadian}

Hasil penelitian analisis jalur yang diilustrasikan pada Gambar 1, menunjukkan bahwa varibel kepribadian berpengaruh terhadap preferensi pemilihan pekerjaan sebagai wirausaha, bekerja di UKM atau bekerja di MNC. Secara keseluruhan, variable kepribadian memoderasi job factors dengan pemilihan pekerjaan dengan loading factor sebesar 0,854. Adapun uraian secara terperinci untuk masing-masing varibel kepribadian adalah sebagai berikut.

Keramahan (agreeableness) adalah dimensi kepribadian telah lama dikaitkan dengan ramah, hubungan kooperatif yang dilakukan individu. Menurut Teo dan Poon (1994), mahasiswa Singapura percaya bahwa UKM menawarkan hubungan manajerial yang lebih tinggi. Sehingga H3 diterima, yang dinyatakan bahwa: keramahan (agreeableness) akan berhubungan positif dengan preferensi bekerja di UKM daripada di perusahaan multinasional (MNC) atau berwirausaha

Tingginya tingkat keterbukaan terhadap pengalaman (openness to experience) telah dikaitkan dengan individu yang kreatif dan secara intelektual ingin tahu. Teo dan Poon (1994) lapangan kerja di UKM menawarkan tanggung jawab lebih besar, wewenang dan keterlibatan dalam pengambilan keputusan. Berdasarkan keyakinan bahwa individu yang kreatif dan memiliki rasa ingin tahu yang intelek akan lebih suka bekerja untuk sebuah organisasi yang memungkinkan mereka untuk menjadi kreatif dan lebih terlibat dengan pengambilan keputusan. Sehingga $\mathbf{H 4}$ berikut diterima: Keterbukaan (openness to experience) terhadap pengalaman akan berhubungan positif dengan preferensi untuk bekerja dengan UKM daripada di perusahaan multinasional (MNC) atau berwirausaha.

Individu yang memiliki kesadaran (conscientiousness) tinggi dianggap lebih loyal dan gigih dan memiliki etika kerja yang lebih tinggi, yang dapat membawa kesuksesan yang lebih besar, gaji yang lebih tinggi dan promosi. Teo dan Poon (1994) mencatat bahwa mahasiswa percaya ada kesempatan yang lebih besar untuk gaji dan prospek karir jangka panjang di MNC. Oleh karena itu diduga bahwa individu-individu yang memberikan nilai tinggi pada dimensi kesadaran mungkin memilih untuk bekerja untuk perusahaan multinasional (MNC) yang menawarkan gaji dan kemajuan peluang yang lebih besar. Demikian pula pada hasil penelitian ini $\mathbf{H 5}$ yang dinyatakan berikut diterima, yaitu: Kesadaran (conscientiousness) akan berhubungan positif dengan preferensi untuk bekerja di perusahaan multinasional (MNC) daripada di UKM atau berwirausaha.

Hasil penelitian pada gambar 1 menunjukkan bahwa kesetabilan emosi secara tidak berhubungan dengan preferensi untuk bekerja dengan perusahaan multinasional (MNC) daripada di UKM atau berwirausaha dengan loading factor dibawah standar yaitu 0,400. 
Hasil penelitian mengindikasikan bahwa kestabilan emosi (emotional stability) mengacu pada tingkat kecemasan seseorang dan seberapa aman mereka bekerja sebagai wirausaha, di UKM atau MNC sebagai variable moderating mempengaruhi persepsi mahasiswa untuk memilih pekerjaan. Sehingga H6 yang menduga kestabilan emosi (emotional stability) akan berhubungan positif dengan preferensi untuk bekerja dengan perusahaan multinasional (MNC) daripada di UKM atau berwirausaha, diterima.

Berdasarkan hasil analisis jalur di gambar 1, maka hipotesis ke enam diterima, karena individu yang kestabilan emosinya kurang mungkin akan lebih yakin bekerja untuk sebuah MNC di mana terdapat persepsi bahwa MNC menawarkan keamanan kerja dan kondisi kerja yang lebih baik dari UKM

Extroversion berhubungan dengan kemudahan individu dalam bergaul dan sikap assertif atau tegas. Individu dengan skor extroversion yang tinggi diyakini untuk mencari pekerjaan yang berhubungan dengan interaksi dan hubungan yang bermanfaat. Meskipun UKM yang dianggap memiliki hubungan manajerial berkualitas tinggi, daya tarik UKM ke individu yang ekstrovert memiliki perbedaan yang tipis dengan di perusahaan multinasional. Kita percaya bahwa ekstrovert mungkin sama-sama sukses baik di UKM dan perusahaan multinasional ekstroversi mungkin tidak menjadi prediktor preferensi untuk pekerjaan baik UKM atau perusahaan multinasional.

Pengaruh extraversion memiliki loading factor yang tinggi baik berpengaruh langsung terhadap preferensi kerja, maupun sebagai variable moderating. Sehingga dapat disimpulkan H7 diterima, yaitu tidak ada hubungan yang signifikan antara ekstroversi dan preferensi untuk pekerjaan di UKM atau MNC atau berwirausaha.

Program pendidikan S1 dan D3 memiliki kesempatan yang sama untuk berkerja sebagai wirausaha, bekerja di UKM atau bekerja di perusahaan multinasional (MNC). Sehingga $\mathbf{H 8}$ yang menduga tidak ada hubungan yang signifikan antara program pendidikan dan preferensi untuk pekerjaan di UKM atau MNC atau berwirausaha, ditolak. Hasil penelitian tersebut ditunjukkan pada gambar 4 yaitu program pendidikan memiliki pengaruh terhadap preferensi pemilihan pekerjaan, hal ini bisa disebabkan karena adanya penekanan kompetensi yang berbeda antara program pendidikan S1 dengan D3, sehingga hipotesis 8 ditolak.

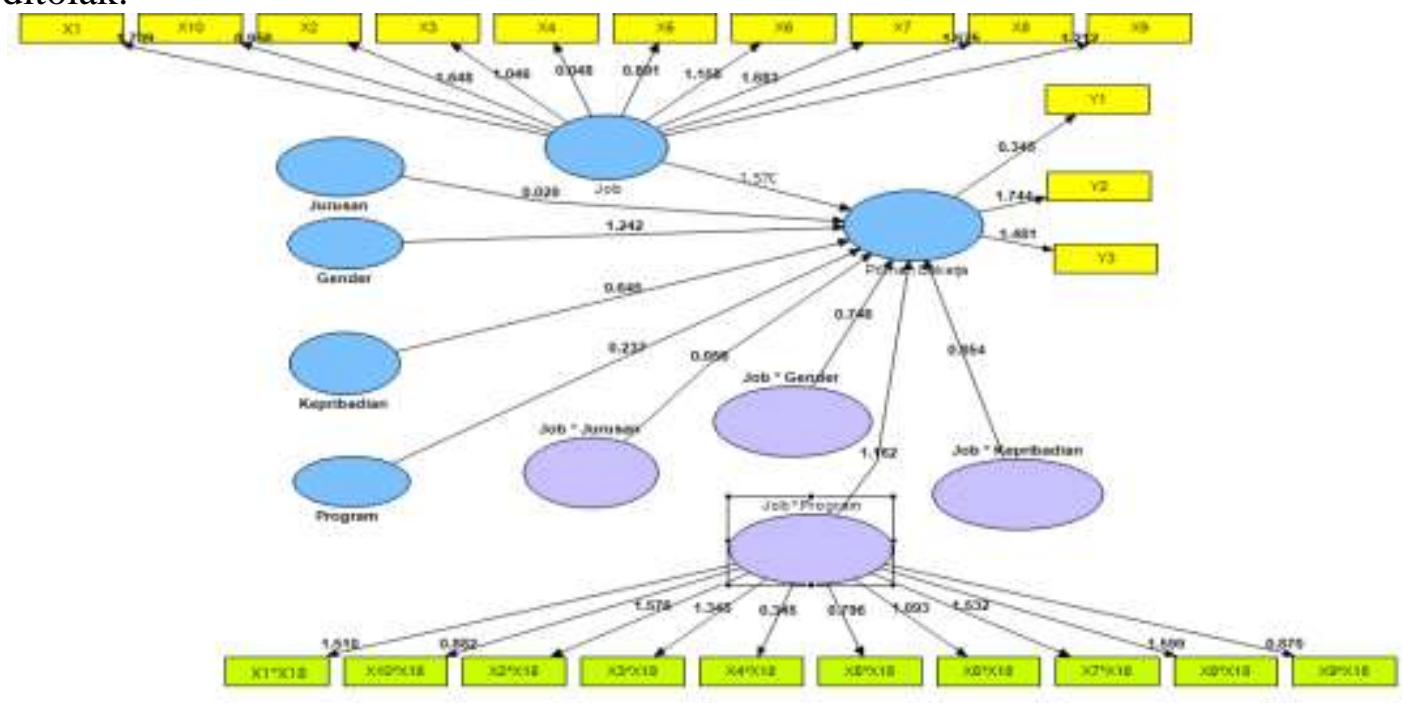

Gambar 4. Persepsi Mahasiswa Bisnis FE UIN Maliki Malang terhadap Pemilihan Bekerja sebagai Wirausaha, UKM atau MNC dengan Program Pendidikan sebagai Variabel Moderating 


\section{Simpulan Dan Saran}

Hasil penelitian persepsi mahasiswa bisnis Fakultas Ekonomi UIN Maulana Malik Ibrahim Malang, yang terdiri dari 3 jurusan Akuntansi, Manajemen dan Perbankan dengan tingkat program pendidikan S1 dan D3 mengenai pilihan bekerja sebagai wirausaha, bekerja di UKM atau di perusahaan multinasional (MNC) dengan jurusan, jenis kelamin (gender), kepribadian dan program pendidikan sebagai variable moderating akan membantu pihak fakultas maupun universitas dalam membekali mahasiswa keahlian dan ketrampilan penunjang kompetensinya.

Hasil penelitian terhadap persepsi mahasiswa ini juga memiliki manfaat yang sangat signifikan 1) untuk review muatan mata kuliah kewirausahaan agar bisa mengakomodir situasi bisnis terkini, 2) sebagai dasar pengembangan kurikulum masing-masing jurusan atau program pendidikan, 3) pengembangan kompetensi serta keterampilan yang dapat menunjang mahasiswa dalam pemilihan karirnya dan 4) dasar perencanaan lulusan unggulan untuk bekerja di lini bisnis utama terutama yang menunjang laju perkembangan UIN Maulana Malik Ibrahim sebagai salah satu WCU.

\section{DAFTAR PUSTAKA}

BPS, 2012. Statistik Usaha Kecil dan Menengah Tahun 2011-2012 diakses dari http://www.depkop.go.id

Fadjri, A.N. 2012. Jumlah Wirausaha RI Naik Jadi $1,56 \%$. http://entrepreneur.bisnis.com/read/20120304/88/67018/jumlah-wirausaha-ri-naik adi1-56-percent. Diunduh 20 Maret 2014.

Goldberg, L. R. (1981). Language and individual differences: The search for universals in personality lexicons. In L. Wheeler (Ed.), Review of personality and social psychology. Vol. 2, pp. 141-165). Beverly Hills: Sage.

Hollingsworth, A.T., Klatt, L.A. dan Zimmerer, T.W. 1974. Zn Untapped Resource for Small Business: Business School Graduates. Journal of Small Business Management, 12 (1), 42-46.

International Personality Item Pool (2001). A Scientific Collaboratory for the Development of Advanced Measures of Personality Traits and Other Individual Differences (http://ipip.ori.org/)

Kementerian Koperasi dan Usaha Kecil dan Menengah Republik Indonesia, 2014. Kriteria Usaha Mikro, Kecil dan Menengah Menurut UU No. 20 Tahun 2008 Tentang UMKM.

http://www.depkop.go.id/index.php?option=com_content\&view=article\&id=129.

Diunduh 25 Maret 2014

Lee Grubb, W., Harris, M.L. dan MacKenzie, W. I. (2007). Business Students' Perceptions of Employment in Small and Medium-Sized Enterprises Versus Multinational Corporations: Investigating The Moderating Effects of Academic Major, Gender, and Personality. Journal of Small Business Strategy; Fall 2006/Winter 2007; 17, 2; ProQuest, pg. 27 
McCrae, R. R., \& Costa, P. T. (1991). Adding liebe und arbeit : The full five-factor model and well being. Personality and Social Psychology Bulletin, 17, 227-232.

Moy, J. W., \& Lee, S. M. (2002). The Career Choice of Business graduates: SMEs or MNCs? Career Development International, 7(6/7), 339-347.

Organ, D. W., \& Lingl, A. (1995). Personality, Satisfaction, and Organizational Citizenship Behavior. Journal of Social Psychology, 135, 339-350.

Sugihandari, 2012. Saatnya Mengembangkan Potensi dengan Berwirausaha. http://health.kompas.com/read/2012/11/27/06103437/Saatnya.Mengembangkan.Poten si.dengan.Berwirausaha. Diunduh 20 Maret 2014.

Suls, J., Green, P., \& Hillis, S. (1998). Emotional Reactivity to Everyday problems, affective inertia and neuroticism. Personality and Social Psychology Bulletin, 24, 127-136.

Teo, H. A., \& Poon, J. T. F. (1994). Career Choice of Undergraduates and SMEs in Singapore. The International Journal of Career Management, 6(3), 20-26.

Tupes, E. C., \& Christal, R. C. (1961). Recurrent Personality Factors Based on Trait Ratings (Technical Report): Lackland Air Force Base.

Van der Sijde, P., Nair, P. dan During, W. 2013. Graduates' Perception of Employment in SMEs and Large Enterprises. International Journal of Business and Social Science Vol. 4 No. 6; June 2013

Watson, D., \& Clark, L. A. (1997). Extroversion and Its Positive Emotional Core. In R. Hogan and J. A. Johnson, \& S. R. Briggs (Eds.), Handbook of personality psychology (pp. 767-793). San Diego, CA: Academic Press.

Winter, D. G., \& Barenbaum, N. B. (1999). History of Modern Personality Theory and Research. In L. A. Pervin and O. P. John, Handbook of personality: Theory and research (2nd ed.,pp. 3-27). New York: Guilford.

Yamin, S. dan Kurniawan, H. 2011. Partial Least Square Path Modeling. Penerbit Salemba Infotek. Jakarta.

Yamin, S. dan Kurniawan, H. 2014. SPSS Complete: Teknik Analisis Statistik Terlengkap dengan Software SPSS. Penerbit Salemba Infotek. Jakarta. 